\title{
POLITYKA OPARTA NA KLASTRACH JAKO CZYNNIK STYMULUJĄCY INNOWACYJNOŚĆ GOSPODARKI UNII EUROPEJSKIEJ
}

\section{Wprowadzenie}

W strategii lizbońskiej Unia Europejska założyła, iż w oparciu o ideę rynku wewnętrznego, wiele reform oraz odpowiednie ukierunkowanie pomocy publicznej gospodarka Unii Europejskiej stać się ma najbardziej konkurencyjną gospodarką na świecie ${ }^{1}$. Kolejne dokumenty potwierdzające te założenia, a w szczególności priorytety strategii „Europa 2020”2 oraz programu „Horyzont 2020”, które obejmują m.in. tzw. rozwój inteligentny (smart growth) oraz utrzymują, iż istotnym elementem polityki gospodarczej Unii Europejskiej jest plan rozwoju gospodarczego skoncentrowany na innowacjach. W tym celu Unia Europejska prowadzi w wielu obszarach interesującą politykę, mającą na celu poniesienie innowacyjności i produktywności gospodarki³. Jest to m.in. polityka oparta na klastrach, będąca przedmiotem niniejszego opracowania.

W ostatnich latach można zaobserwować wzrost zainteresowania Komisji Europejskiej oraz poszczególnych państw członkowskich nowym typem polityki gospodarczej opartej na koncepcji klastra. W 2008 roku został wydany jeden z najważniejszych dokumentów dotyczący klastrów w polityce Unii Europejskiej - Komunikat Komisji Europejskiej skierowany do Rady Europejskiej, Parlamentu Europejskiego, Europejskiego Komitetu Ekonomicznego i Społecznego oraz Komitetu Regionów dotyczący klastrów o znaczeniu światowym w Unii Europejskiej oraz wdrażania szeroko zakrojonej strategii w zakresie innowacji ${ }^{4}$. Głównym celem Komunikatu jest tworzenie efektywnych warunków dla wspierania rozwoju inicjatyw klastrowych

\footnotetext{
1 Strategia Lizbońska - droga do sukcesu zjednoczonej Europy, UKIE, Warszawa, 05.2002.

2 Komunikat Komisji Europejskiej, Europa 2020. Strategia na rzecz zrównoważonego i inteligentnego rozwoju sprzyjającego włączeniu społecznemu, KOM (2010) 2020, Bruksela, 3.03.2010, s. 5.

3 Por. decyzja nr 1639/2006/WE Parlamentu Europejskiego i Rady z dnia 24 października 2006 r. ustanawiająca Program Ramowy na rzecz Konkurencyjności Innowacji (2007-2013).

${ }_{4}$ DzUrz. UE L 288/7 z dnia 30.10.2008, decyzja Komisji z dnia 22.10.2008 ustanawiająca europejską grupę ds. polityki klastrowej (2008/824/WE).
} 
w Europie. Temat klastrów w szczególny sposób został włączony w jeden z siedmiu projektów przewodnich (flagship initiatives) wyodrębnionych w strategii „Polityka przemysłowa w erze globalizacji”" Właśnie w ramach tego projektu Komisja Europejska proponuje wpieranie klastrów.

Polityka oparta na klastrach jest przykładem coraz większego kojarzenia problematyki innowacyjności z sieciami, współpracą, powiązaniami w różnych konstelacjach instytucjonalnych i przestrzennych ${ }^{6}$. Przyczyny tego stanu rzeczy upatrywać można w postępie globalizacji, we wzroście zainteresowania badaczy nauk społecznych tzw. miękkimi zmiennymi ${ }^{7}$, bądź potrzebą powrotu w ekonomii do myślenia systemowego, u którego podstaw leży założenie o holistycznym postrzeganiu interpretowania rozmaitych form jako struktur powiązanych ze sobą rozmaitymi relacjami ${ }^{8}$.

Można zaryzykować tezę, że koncepcja klastrów jest efektem zapotrzebowania w ekonomii na nowy sposób kreowania konkurencyjności z uwzględnieniem szerokiego wachlarza czynników. Zainteresowanie problematyką zaowocowało rosnącą liczbą analiz, badań funkcjonowania klastrów w Unii Europejskiej, narodowymi programami ich mapowania, a w konsekwencji doprowadziło do wyłonienia się polityki opartej na klastrach (cluster based policy - CBP). Polityka ta może być wdrażana holistycznie z uwzględnieniem wszystkich poziomów analitycznych. Należy zaznaczyć, że częściowe bądź całościowe rozwiązania dotyczące zaleceń CBP zostały zastosowane przez większość państw członkowskich OECD 9 . Z perspektywy Komisji Europejskiej promowanie rozwoju klastrów stanowi jedno z zasadniczych narzędzi w osiąganiu ambitnych celów założonych w strategii lizbońskiej oraz strategii „Europa 2020”, stąd można to zadanie uznać za znaczące wyzwanie gospodarcze stojące przed całą Unią Europejską, a także przed poszczególnymi krajami członkowskimi ${ }^{10}$.

5 Komunikat Komisji do Parlamentu Europejskiego, Rady, Europejskiego Komitetu Ekonomiczno-Społecznego i Komitetu Regionów „Zintegrowana polityka przemysłowa w erze globalizacji: Konkurencyjność i zrównoważony rozwój na pierwszym planie”, KOM (2010) 614 wersja ostateczna.

${ }^{6}$ A. Olechnicka, A. Płoszaj, Sieci wspólpracy receptą na innowacyjność regionu?, w: Europejskie wyzwania dla Polski i jej regionów, red. A. Tucholska, MRR, Warszawa 2010, s. 200 .

7 Por. P. Sztompka, Zaufanie. Fundament społeczeństwa, Znak, Kraków 2007, s. 69.

8 A. Piekarczyk, K. Zimniewicz, Myślenie sieciowe w teorii i praktyce, PWE, Warszawa 2010, s. 29.

9 Networks of enterprises and local development. Competing and Co-operating in Local Productive Systems, OECD, Paris 1996

10 T. Brodzicki, S. Szultka, Koncepcja klastrów a konkurencyjność przedsiębiorstw, „Organizacja i Kierowanie" $\mathrm{nr} 4,2002$, s. 1. 


\section{Klastry - analiza pojęcia}

Do identyfikacji i analizy klastrów wykorzystuje się m.in. dorobek analizy sieciowej. Analiza sieci ma długą tradycję, niezwykle bogatą literaturę i wiele efektownych zastosowań w różnych obszarach i polach badawczych. Szeroki nurt badań sieciowych został rozwinięty na gruncie nauk społecznych jako analiza sieci społecznych ${ }^{11}$. Przedmiotem jej zainteresowania są zbiory obiektów społecznych rozpatrywane wraz $\mathrm{z}$ istniejącym między nimi układem powiązań ${ }^{12}$. Analiza sieciowa nie jest bynajmniej wynalazkiem ostatniej dekady. Sieć stanowi metaforę opisu narzędzia, jakim człowiek posługiwał się od zarania dziejów do połowu ryb ${ }^{13}$. Posiada swoje źródła filozoficzno-teoretyczne w XIX wieku, m.in. w dorobku Alfreda Marshalla; pisał on w Zasadach ekonomii o okręgach przemysłowych, które utożsamiał $\mathrm{z}$ regionalnymi skupiskami przedsiębiorców ${ }^{14}$. Jej kluczowe ślady można odnaleźć w pismach XX-wiecznych badaczy, najczęściej jako ukrytą ideę, będącą kamieniem węgielnym innych struktur czy form, jak w idei „więzi sieciowej” obecnej w pismach Emila Durkheima czy koncepcji gemeinschaft i gesellschaft Ferdynanda Tönniesa.

Wśród współczesnych prac bezpośrednio wpływających na jej rozwój wyróżnić należy m.in. prace Marka Granovettera o „sile słabych więzi”, w których dowodził ich szczególnej funkcjonalności ${ }^{15}$, prace Ronalda S. Burta i jego koncepcję „strukturalnych luk" podkreślającą znaczenie pozycji w strukturze sieci, a nie relacji ${ }^{16}$, koncepcję „małych światów” Jeffreya Traversa i Stanleya Milgrama stworzoną na podstawie eksperymentów wskazujących, że każde dwie osoby dzieli od siebie przeciętnie pięć innych osób, tzw. koncepcję sześciu stopni oddalenia ${ }^{17}$, a także prace Manuel Castellsa związane z nieco odmiennym nurtem teoretycznym, podkreślające jednak procesy informatyzacji i globalizacji w koncepcji społeczeństwa sieciowego ${ }^{18}$.

Generalnie rzecz ujmując, różnorodne koncepcje sieci, które zostały jedynie zasygnalizowane i świadomie ze względu na objętość niniejszego tekstu pominięte,

11 Por. A. Wicher-Baluta, Znaczenie kapitału społecznego opartego na analizie sieciowej w metodach zatrudniania pracowników, w: Praca, społeczeństwo, gospodarka, red. J. Osiński, Oficyna Wydawnicza SGH, Warszawa 2011, s. 222-223.

12 T. Soziański, Sieć społeczna, w : Encyklopedia socjologii, t. 3, Oficyna Naukowa, Warszawa 2000, s. 28.

13 Metafora użyta przez K. Zimniewicza; por. A. Piekarczyk, K. Zimniewicz, op.cit., s. 9.

14 R. Heilbroner, Wielcy ekonomiści: czasy, życie, idee, PWE, Warszawa 1993.

15 M. Granovetter, The Strength of Weak Ties, „American Journal of Sociology” Nr 78, IV/1978, s. $1360-1380$.

16 R.S. Burt, The Network Structure of Social Capital, red. R.I. Sutton, B.M. Staw, „Research in Organizational Behavior" Nr 22, JAJ Press, Greenwich 2000, s. 2.

17 J. Travers, S. Milgram, An Experimental Study of the Small World Problem, „Sociometry” Nr 32 (4), 1969, s. 425-443.

18 M. Castells, Społeczeństwo sieci, Wydawnictwo Naukowe PWN, Warszawa 2007. 
explicite odnoszą się do powiązań, relacji, bądź stosunków, które stanowią podstawową cechę każdej z nich. Koncentrują się one na kształcie struktury społecznej, pozycji jednostek w tychże strukturach oraz wynikających z nich korzyści. Wyjściowy problem $\mathrm{w}$ analizie sieciowej stanowi wymiana pomiędzy partnerami transakcji ${ }^{19}$.

Efekt sieci jest szczególnie widoczny w problematyce dotyczącej klastrów. Pojęcie „klastra” (cluster) w aspekcie ekonomicznym po raz pierwszy zostało użyte przez Michaela Portera. Wedle jego definicji klaster to "geograficzne zjawisko wzajemnie powiązanych firm, wyspecjalizowanych dostawców, jednostek świadczących usługi, firm działających w pokrewnych sektorach i związanych z nimi instytucji (np. uniwersytetów, jednostek normalizacyjnych i stowarzyszeń branżowych) w poszczególnych dziedzinach, konkurujących między sobą, ale również współpracujących”20. Pisał on, iż klastry osiągające masę krytyczną (niezbędna liczba firm i innych instytucji tworząca efekt aglomeracji) i odnoszące niezwykłe sukcesy konkurencyjne w określonych dziedzinach działalności są uderzającą cechą niemal każdej gospodarki narodowej, regionalnej, stanowej, a nawet wielkomiejskiej, głównie w krajach gospodarczo rozwiniętych ${ }^{21}$.

Innymi słowy, klastry wedle Micheala Portera stanowią nowy sposób myślenia o konkurencyjności, charakteryzują się one dużym znaczeniem dla gospodarek w różnych skalach i zróżnicowanych przestrzennie. By mogły powstać, warunkiem sine qua non jest tzw. efekt aglomeracji, a więc konieczność występowania na danym terenie określonej liczby firm i instytucji ${ }^{22}$.

W literaturze przedmiotu znajdujemy wiele propozycji definicji klastra, jednakże wszystkie one są zgodne co do czterech zasadniczych cech. Należą do nich: powiązania poziome i pionowe między podmiotami i instytucjami, koncentracja na określonym obszarze współzależnych podmiotów gospodarczo działających w tych samych sektorach przemysłu, ciągła konkurencja oraz współpraca. Krótko mówiąc, fenomen klastra opiera się na jednoczesnym zaistnieniu tych specyficznych cech, a więc bliskiego sąsiedztwa przedsiębiorstw konkurujących ze sobą w tych samych lub pokrewnych branżach, pomiędzy którymi występują wzajemne oddziaływania. Sytuacja ta sprzyja płynnemu przepływowi informacji rynkowych i technicznych. Można zatem wnioskować, że aktywność podmiotów gospodarczych jest wzmagana bądź ograniczana przez otoczenie. Obok efektu aglomeracji i efektu naśladownictwa w klastrach dostrzec można pewne elementy związane $\mathrm{z}$ występowaniem dóbr

19 Por. A.L. Barabasi, E. Bonabeau, Scale-Free Networks, „Scientific American” Nr 288, 05.2003, s. $60-69$.

20 M.E. Porter, Porter o konkurencji, PWE, Warszawa 2001, s. 246.

21 T. Brodzicki, S. Szultka, op.cit., s. 2.

22 M.E. Porter, op.cit., s. 199. 
wspólnych. Założenie bowiem wspólnego celu wymaga od uczestników klastra wypracowania określonego stanowiska, będącego rezultatem poskromienia indywidualnych, egoistycznych bodźców na rzecz wspólnego stanowiska, kierunku działania bądź ogólnie przyjętej polityki.

Klasyczne dzieło M. Portera wskazuje, że o wyjątkowości klastrów decydują jego cechy ${ }^{23}$. Pierwsza dotyczy ponadsektorowego charakteru klastra. Oznacza ona przede wszystkim, iż w skład typowego klastra wchodzą zarówno przedsiębiorstwa określonych branż, jak i instytucje badawczo-rozwojowe, fundusze kapitałowe, firmy szkoleniowe czy marketingowe. Druga cecha związana jest z nieformalnym charakterem tych ugrupowań wchodzących w skład klastra. Koncepcja Portera podkreśla, że są to ugrupowania płynne, tworzone wokół określonych technologii i lokalizacji w sposób nieformalny, a więc bez opierania się na formalnej strukturze, przy wykorzystaniu lokalnych powiązań strukturalnych ${ }^{24}$. Kolejną cechą jest ich zależność od pozycji konkurencyjnej sektorów, co oznacza w rzeczywistości, iż klastry mogą się tworzyć i zamykać wokół tychże sektorów ${ }^{25}$.

Problemy etymologiczne związane $\mathrm{z}$ wypracowaniem jednoznacznej definicji klastra wynikają z trudności z uchwyceniem charakteru samego zjawiska. Pojawienie się klastra $w$ danym obszarze wynika $z$ jednoczesnego zaistnienia wielu czynników geograficznych, społecznych, politycznych oraz kulturowych wpływających na wyłonienie się przewagi konkurencyjnej nad innymi lokalizacjami. Struktury klastrowe powstające $\mathrm{w}$ określonych regionach mają więc specyficzny charakter ${ }^{26}$. W literaturze przedmiotu podejmuje się próby klasyfikacji klastrów za pomocą kryteriów, do których można zaliczyć27:

1) kryterium rozwoju: klastry embrionalne, wzrostowe, dojrzałe, schyłkowe;

2) kryterium kreowania miejsc pracy: klastry o rosnącym, stabilnym bądź malejącym zatrudnieniu;

3) kryterium zasięgu terytorialnego: klastry o zasięgu lokalnym, regionalnym, narodowym lub ponadnarodowym;

4) kryterium liczby horyzontalnie powiązanych sektorów: klastry wąskie i szerokie;

23 A. Sosnowska, System wspierania, innowacji i transferu technologii w krajach UE i w Polsce - poradnik przedsiębiorcy, Wydawnictwo Instytutu Technologgi Eksploatacji, Warszawa 2003, s. 59.

${ }^{24}$ M.E. Porter, op.cit., s. 246.

25 J. Hołub-Iwan, M. Machałowska, Rozwój klastrów w Polsce. Raport z badań, MRR, Szczecin 2008, s. 9.

${ }^{26}$ M.E. Porter, op.cit., s. 30.

27 J.M. Enright, Regional Clusters: What we know and what should we know, paper prepared for the Kiel Institute International Workshop on Innovation Clusters and Interregional Competition, Kiel, 12-13.11.2001, za: T. Brodzicki, S. Szultka, op.cit., s. 4. 
5) kryterium liczby stadiów łańcucha produkcyjnego: klastry głębokie - obejmujące wszystkie stadia łańcucha produkcyjnego, klastry płytkie - obejmujące jeden lub kilka etapów;

6) kryterium pozycji konkurencyjności: klastry będące liderami światowymi, krajowymi lub klastry posiadające słabą lub przeciętną pozycję konkurencyjną;

7) kryterium innowacyjności i zaawansowania technologicznego - klastry niskich, średnich i wysokich technologii.

Sposoby rozumienia i porządkowania klastrów można także klasyfikować zgodnie z kilkoma kryteriami, np. dotyczącymi wielkości i struktury własności podmiotów. Na tej podstawie można wskazać trzy rodzaje klastrów:

a) klastry pokrewne włoskim dystryktom przemysłowym, których najbardziej znanym przykładem jest słynna amerykańska Dolina Krzemowa; ten typ klastra charakteryzuje się m.in. dominacją małych i średnich przedsiębiorstw, silną specjalizacją oraz silną wzajemną rywalizacją z jednoczesnym systemem powiązań sieciowych opartych przede wszystkim na zaufaniu; występowanie tych czynników umożliwia elastyczną specjalizację, wysoką produktywność oraz kreuje znaczący potencjał innowacyjny;

b) klaster wyznaczający oś, charakteryzujący się współistnieniem na danym terenie dużych przedsiębiorstw powiązanych hierarchicznie z rozległą grupą firm sektora MSP; klaster tego typu bazuje w dużym stopniu na sile wielkich korporacji, charakteryzując się jednocześnie elastycznością działania oraz wykorzystaniem przewagi kosztowej;

c) klaster satelitarny z dominującym udziałem małych i średnich przedsiębiorstw uzależnionych od firm zewnętrznych; jego przewaga lokalizacyjna opiera się $\mathrm{z}$ reguły na niższych kosztach (np. Research Triangle Park w Północnej Karolinie czy region Manaus w Brazylii) ${ }^{28}$.

Zaprezentowane klasyfikacje wskazują, iż klastry można opisywać na podstawie różnych zestawień typowych cech. W Polsce problematyka związana z celową koncentracją przemysłu i powstawaniem zlokalizowanych systemów produkcyjnych ma niedługą tradycję. Można więc uznać, że większość istniejących klastrów to klastry embrionalne lub wzrostowe, a także klastry o zasięgu regionalnym lub lokalnym.

Warto wskazać, iż nie ma jednego, uniwersalnego modelu klastra. Każdy jest wyjątkowy, a jego powstanie zależne jest od wielu czynników, w tym także od świata zewnętrznego, czyli otoczenia, które w tej koncepcji jest warunkiem egzystencji przedsiębiorstwa. Powstający lub istniejący klaster wymaga zatem

\footnotetext{
28 Ibidem, s. 2.
} 
zindywidualizowanego podejścia, analizy kontekstowej oraz specyficznego, jemu tylko właściwego wsparcia.

\section{Korzyści z powstawania klastrów: poziom mikro i makro}

Klastry w wolnym tłumaczeniu to „koncentracja”, „grono”, „zalążek” bądź „,kkupisko" przedsiębiorstw pokrewnej branży, pomiędzy którymi występują relacje współpracy ${ }^{29}$. Koncepcja klastra stanowi syntetyczne podejście opierające się z jednej strony na analizie społecznych uwarunkowań, gdzie korzyści zależą od jego społecznej struktury, z drugiej zaś na ekonomicznym indywidualizmie bodźców wpływających na dokonywane przez określone jednostki wybory, a także na uwzględnieniu przesłanek związanych z występowaniem poczucia wspólnego interesu. Ten eklektyzm metodologiczny zauważalny w problematyce klastrów wynika z zastosowania w niej metod i technik badawczych pochodzących z różnych dyscyplin.

Zasadnicza teza dotycząca klastrów leży w przekonaniu, iż klastry wpływają pozytywnie na podnoszenie innowacyjności gospodarki, a także samych przedsiębiorstw $^{30}$. Problematyka klastrowa wiąże się z występowaniem w tym kontekście wielu korzyści zarówno dla uczestników klastra, jak i dla całej gospodarki wynikających z roli, jaką pełni klaster. Tym samym można te korzyści określić jako korzyści w skali mikro, a więc korzyści, które czerpią uczestnicy klastra, a także korzyści w skali makro, gdzie funkcjonują one jako rodzaj wspólnego dobra.

Na podstawie analizy konkretnych przypadków można stwierdzić, że prowadzenie działalności gospodarczej w ramach efektywnie funkcjonujących klastrów przekłada się pozytywnie na poziom produktywności ${ }^{31}$. Korzyści te są wynikiem dostępu do wyspecjalizowanych, a więc dostawanych do potrzeb danych sektorów czynników produkcji.

Rolę klastrów w generowaniu korzyści na poziomie przedsiębiorców można zatem ująć następująco:

1) wzmacnianie współpracy poprzez kreację i podtrzymywanie sieci powiązań,

2) stymulowanie konkurencyjności,

3) identyfikacja możliwości innowacyjnych,

29 E. Wojnicka, P. Rot, P. Tamowicz, T. Brodzicki, Regionalny system innowacyjny w województwie pomorskim, „Polska Regionów” nr 26, IBnGR, Gdańsk 2001, s. 10.

${ }^{30}$ Komunikat Komisji Europejskiej, op.cit., s. 5.

31 T. Brodzicki, S. Szultka, P. Tamowicz, Polityka wspierania klastrów. Najlepsze praktyki. Rekomendacje dla Polski, Niebieskie Księgi 2004, rekomendacje nr 11, IBnGR, Warszawa 2004, s. 8. 
4) dyfuzja i absorpcja innowacyjności,

5) kreacja nowych przedsiębiorstw,

6) redukcja kosztów wymiany i transferu wiedzy,

7) stymulacja miejsc pracy.

Przestrzenna bliskość partnerów ma istotne znaczenie w kontekście generowania korzyści związanych z powstaniem klastra. Formalne i nieformalne powstawanie więzi w jego obszarze wzmacnia współpracę, poczucie identyfikacji z grupą oraz założonymi jej wspólnymi celami. Zasadniczy element w powstawaniu struktur klastrowych stanowi kreowanie sieci powiązań pomiędzy partnerami, nawiązywaniu relacji jednostkowych. Tworzenie więzi pomaga w powstawaniu sieci zależności sprzyjających dokonywaniu wymian różnorodnych dóbr, maszyn, usług czy idei, dostępu do cennych informacji, technologii etc. Kontakty między jednostkami tworzą warunki poszerzania horyzontów myślowych, nawiązywania dialogu, który sprzyja uczeniu się od siebie nawzajem, odkrywaniu powiązań między elementami dotychczas nieuświadamianymi czy minimalizowaniu błędów w procesach decyzyjnych. Przyjmowanie jednej perspektywy analizy problemu jest dość powszechnym błędem popełnianym przez przedsiębiorstwa. Tendencja do radykalnego upraszczania wynika przecież z jednostronnego oglądu sytuacji, presji na podjęcie szybkiej decyzji lub wykorzystanie możliwe jak najprostszych metod decyzyjnych ${ }^{32}$. Nawiązywanie relacji pozwala te błędy eliminować dzięki myśleniu sieciowemu. Efektem tego są nowe możliwości innowacyjne, szersza, bardziej rozległa sieć powiązań, lepsze rozumienie problemów, a w rezultacie lepsza współpraca.

W ten sposób wykorzystując dialektyczne połączenie konkurencji i współpracy, poprzez wykorzystanie zasobów tkwiących w więziach opartych na zaufaniu, powstaje efekt synergii właściwy występowaniu klastra. Klaster wpływa więc na podniesienie konkurencyjności i produktywności określonych przedsiębiorstw w nim funkcjonujących. Oznacza to, że ułatwia on współpracę, czyniąc ją możliwą dla osiągania wspólnych celów, potęguje korzyści płynące z kapitału ludzkiego i fizycznego. Naciski konkurencyjne w takim gronie powodują występowanie wzmożonej chęci naśladownictwa, a bliskość zaplecza naukowo-badawczego i współpraca zwiększają szybkość wprowadzenia innowacji oraz redukują ich koszty ${ }^{33}$. Innowacyjność zaś ma ogromne znaczenie w procesach uczenia się, a nade wszystko w dyfuzji i absorpcji wiedzy ${ }^{34}$. Opiera się ona na ciągłym jej stymulowaniu, wyrażając się $\mathrm{w}$ twórczym procesie uczenia się, transferze technologii i rozwoju istniejących

\footnotetext{
32 A. Piekarczyk, K. Zimniewicz, op.cit., s. 31.

33 A. Olechnicka, A. Płoszaj, op.cit., s. 209.

34 Por. H. Lauder, Innovation, Skill Diffusion and Social Exclusion, w: P. Brown, A. Green, H. Lauder, Globalization, Competitiveness and Skill Formation, Oxford University Press, New York 2001, s. 163.
} 
koncepcji. Dyfuzja innowacji związana jest zaś z powstawaniem nowych przedsiębiorstw, a w konsekwencji z powstawaniem nowych miejsc pracy.

Korzyści funkcjonowania klastra można także rozpatrywać z perspektywy makrosystemowej, gdzie funkcjonowanie klastrów wpływa na podnoszenie innowacyjności całej gospodarki oraz przyczynia się do generowania takich korzyści, które stanowią dobro całych zbiorowości. Rolę klastrów na poziomie makrospołecznym można ująć następująco:

1) kreowanie konkurencyjności i rozwoju społeczno-gospodarczego,

2) dostarczanie ułatwień dla procesów wymiany,

3) podnoszenie innowacyjności regionalnej polityki,

4) generowanie kapitału społecznego.

Powstające i istniejące klastry przyczyniają się do podnoszenia konkurencyjności gospodarki i rozwoju społeczno-gospodarczego ${ }^{35}$. Działania polegające na wzmacnianiu pozycji konkurencyjnej klastra poprzez ukierunkowanie rozwoju oraz wzrost specjalizacji kooperujących przedsiębiorstw i instytucji przyczyniają się do efektywnej kreacji w skali lokalnej wyspecjalizowanych czynników produkcji. Model gospodarki, którego cechą była stabilność, wyczerpał się. Przejście od systemu fordowskiego do posfordyzmu spowodowało, iż rynek stał się bardziej zmienny i sfragmentaryzowany, zaczął wymagać przede wszystkim elastyczności i specjalizacji ${ }^{36}$. Wymóg flexibility i jakości spowodował, że na znaczeniu zyskały mniejsze przedsiębiorstwa, a także kooperacja pomiędzy nimi oraz wielkimi korporacjami, dla których strategia współpracy z mniejszymi przedsiębiorstwami pozwala zwiększyć zdolności adaptacyjne do nowych wymagań rynku³. Zjawiska te nadają klastrom wartość. Wymagają one od podmiotów gospodarczych przedsiębiorczości, współdziałania, innowacyjności, a więc zachowań, które są tym efektywniejsze, im niższe są koszty transakcyjne. Klastry mogą więc w znaczącym stopniu wpływać na tworzenie stosownego kapitału ludzkiego oraz skuteczną alokację kapitału fizycznego i finansowego dzięki efektywnej współpracy lokalnych jednostek ${ }^{38}$. Co więcej, podmioty gospodarcze uczestniczące $\mathrm{w}$ klastrach dzięki płynnemu przepływowi informacji, wiedzy i doświadczenia zyskują przewagę nad podmiotami, które nie są

35 Por. M.E. Porter, op.cit., s. 246; Biznes międzynarodowy. Od internacjonalizacji do globalizacji, red. M.K. Nowakowski, Oficyna Wydawnicza SGH, Warszawa 2005, s. 409-411.

36 J. Hausner, Postfordowski paradygmat przemysłowy, „Gospodarka Narodowa” 1994, s. 4; J. Gardawski, Dialog społeczny w Polsce. Teoria, historia i praktyka, Oficyna Wydawnicza SGH, Warszawa 2009.

37 T. Kaźmierczak, Kapitał społeczny a rozwój społeczno-ekonomiczny - przeglad podejść, w: Kapitał społeczny. Ekonomia społeczna, red. T. Kaźmierczak, M. Rymsza, Fundacja Instytutu Spraw Publicznych, Warszawa 2007, s. 52.

38 C. Trigilla, Social Capital and Local Development, „European Journal of Social Theory” Nr 4 (4), 2001, s. 434-435. 
uczestnikami klastrów. W przypadku zbiorowości terytorialnych występujące klastry dają określonym regionom przewagę w konkurowaniu o inwestorów zewnętrznych. W tym znaczeniu rola występujących w regionie klastrów wzrasta, zwiększa bowiem możliwości lokalnych jednostek wpływania na rozwój całego regionu. W przyszłości dobrze funkcjonujący w określonym regionie klaster mógłby zostać przekształcony w regionalny system innowacji o charakterze badawczo-naukowym, stanowiąc platformę współpracy pomiędzy instytucjami naukowo-badawczymi a przedsiębiorstwami i jednostkami samorządu terytorialnego. W ten sposób tworzyłby pozytywny klimat dla powstawania innowacji oraz przyczyniałby się do podnoszenia świadomości na temat znaczenia transferu wiedzy dla rozwoju przedsiębiorstw oraz regionu. Jak widać, klaster może stać się swoistym motorem rozwoju regionalnego.

Inną makrosystemową korzyść z występowania klastra można odnieść do pozytywnego wpływania na wzrost kapitału społecznego w określonym regionie. Kapitał społeczny w klasycznym ujęciu związany jest z cechami takimi jak zaufanie, normy i powiązania, które zwiększają sprawność społeczeństwa ${ }^{39}$. Dobrowolna współpraca łatwiejsza jest w określonej zbiorowości, która respektuje oraz reprodukuje normy społeczne związane z tolerancją, zaufaniem i odpowiedzialnością za dobro wspólne. Klastry są naturalnym generatorem tych wartości. W nich jednostki uczą się, że brak umiejętności praktycznego zastosowania zasobów, w tym także zasobów wiedzy i umiejętności, niski poziom zaufania, bierne postawy i brak zaangażowania nie sprzyją współpracy oraz wymagają poniesienia przez nie większych kosztów transakcyjnych. Praktyki zbiorowe oraz potencjały ludzkiej aktywności obywatelskiej, których w pewnym sensie klaster jest „szkołą”, mają bezpośrednie przełożenie na rozwój ekonomiczny ${ }^{40}$. Podnoszenie kapitału społecznego przez klaster odnosi się w związku z tym do takich wartości, jak zaufanie, normy wzajemności oraz określona gotowość do współpracy, kształtując jakość i ilość społecznych interakcji ${ }^{41}$. Z drugiej strony kapitał społeczny przyczynia się do powstawania struktur klastrowych w tym sensie, iż stanowi on odpowiedni „klimat” do jego powstania, zbiór określonych kompetencji, zbiór pewnych zdolności niezbędnych do inicjowania, a następnie budowania i rozwijania polityki klastrowej. Przecież zwiększona chęć do podejmowania ryzyka jest bezpośrednio związana z podejmowaniem działań innowacyjnych. Jeśli więc

39 Por. R. Putnam, R. Leonardi, R.Y. Nanetti, Demokracja w działaniu. Tradycje obywatelskie we współczesnych Włoszech, Wydawnictwo Znak, Kraków 1995, s. 258; J.S Coleman, Social Capital in the Creation of Human Capital, „The American Journal of Sociology” Nr 94, The University of Chicago Press, Chicago 1988, s. $100-101$.

${ }^{40}$ R. Solow, Notes on social capital and economic performance, w: Social Capital. A Multifaceted perspectives, red. P. Dasgupta, I. Serageldin, The World Bank, Washington, D.C. 2000, s. 6.

41 Por. J.S. Coleman, Foundations of Social Theory, The Belknap Press of Harvard University Press, Cambridge, MA-London 1990, s. 304. 
kapitał społeczny dostarcza proaktywnych zachowań i stosownego klimatu, przedsiębiorstwa będą bardziej skłonne do podejmowania ryzyka i wprowadzania innowacji.

Klaster może zatem generować szereg pozytywnych efektów dla swojego bezpośredniego otoczenia, a więc regionu, w którym jest osadzony. Jest on niewątpliwie formą organizacji produkcji o wysokim potencjale innowacyjnym, a tym samym odgrywa kluczową rolę w kreowaniu konkurencyjności poszczególnych przedsiębiorstw i rozwoju społeczno-gospodarczym ${ }^{42}$.

\section{Wyzwania stojące przed polityką rozwoju opartą na klastrach}

W literaturze przedmiotu wyróżnia się dwie metody budowania klastrów w gospodarce: tzw. metodę oddolną (buttom up) - są to klastry tworzone przez grupę firm, a także odgórne tworzenie klastrów - top-down. Te ostatnie są to inicjatywy klastrowe budowane przez władze regionalne. W Polsce wyłaniają się inicjatywy klastrowe zapoczątkowane dzięki środkom z Unii Europejskiej.

Polityka oparta na klastrach (CBP) to zespół działań i instrumentów wykorzystywanych przez władze różnych szczebli dla podnoszenia konkurencyjności gospodarki poprzez stymulowanie rozwoju istniejących, bądź tworzenie nowych systemów klastrowych przede wszystkim na szczeblu regionalnym ${ }^{43}$. Cluster based policy jest uznawana za nowy typ polityki gospodarczej i w tym znaczeniu jej implementacja stanowi wyzwanie dla państw członkowskich Unii Europejskiej. Polityka ta wyróżnia się następującymi elementami ${ }^{44}$ :

1) rynek jest jej siłą napędową,

2) łączy różnorodne podmioty,

3) opiera się na współpracy i wspólnych działaniach,

4) posiada strategiczny charakter - pomaga w kształtowaniu wspólnej wizji,

5) kreuje nową wartość.

Jak zostało zasygnalizowane, nadrzędnym celem polityki opartej na klastrach jest podnoszenie poziomu konkurencyjności sytemu gospodarczego. Jednakże sposoby urzeczywistniania tego celu dla poszczególnych państw członkowskich Unii Europejskiej muszą się między sobą różnić m.in. pod względem ustanowienia priorytetów, szczeblem implementacji tej polityki oraz skalą i zakresem angażowania

${ }^{42}$ J. Hołub-Iwan, M. Machałowska, op.cit., s. 9.

43 T. Brodzicki, S. Szultka, P. Tamowicz, op.cit., s. 16.

${ }^{44}$ Ibidem, s. 16. 
w jej powstawanie działań publicznych. Co więcej, jej realizacja, a także wybór odpowiedniego modelu jest zależny od kontekstu społecznego. Określone wzorce, sposoby działania, poziom kapitału społecznego czy rozpowszechnione etosy pracy mogą być znaczącą barierą we wprowadzaniu tej polityki.

Polityka oparta na klastrach może być realizowana na różnych poziomach bądź na wszystkich poziomach jednocześnie. Zaangażowanie władz może być bardziej pośrednie lub bezpośrednie, w zależności od przyjęcia modelu tworzenia klastrów. Praktyka pokazuje, że w rejonach o stałej tradycji tworzenia klastrów gospodarczo uzasadnione jest tworzenie klastrów w sposób oddolny. Jednocześnie nie należy wykluczać inicjatyw klastrowych stymulowanych odgórnie, gdzie ich powstawanie lub rozwój mogą być wpisane w strategie rozwoju kraju, regionu czy powiatu. Ogólnie rzecz biorąc, jest to polityka niezwykle szeroka i horyzontalna. Wspieranie inicjatyw klastrowych przez władze - w tym animatorów klastra i instytucji organizujących współpracę (institutions for collarborations - IFC) - jest tylko jednym z elementów tej polityki. Pozostałe działania są najczęściej składowymi innego rodzaju polityki: przemysłowej, naukowo-technologicznej, edukacyjnej, dotyczącej sektora MSP, promocji eksportu lub przyciągania inwestorów zagranicznych ${ }^{45}$.

Zasadniczym elementem CBP jest wspieranie interakcji typowych dla klastrów poprzez takie instrumenty, jak: sieci współpracy, centra doskonałości, centra designu, parki naukowo-technologiczne. Nie ma jednego, ogólnie przyjętego modelu polityki rozwoju opartej na klastrach. Niemniej w literaturze przedmiotu można spotkać cztery najbardziej rozpowszechnione metody wspierające rozwój klastrów wyróżnione w raporcie dla holenderskiego Ministerstwa Gospodarki ${ }^{46}$ :

1) metoda kreowania przewagi konkurencyjnej w zakresie kluczowych sektorów gospodarki lub strategicznych łańcuchów wartości dodanej,

2) metoda podnoszenia konkurencyjności sektora MSP (małych i średnich przedsiębiorstw),

3) metoda stymulowania rozwoju regionalnego,

4) metoda intensyfikacji współpracy przemysłu ze sferą badań polegająca na generowaniu innowacji i ich dyfuzji w systemie gospodarczym.

\footnotetext{
45 Raport Ministerstwa Gospodarki, Departament Rozwoju Gospodarki: Kierunki i polityka rozwoju klastrów w Polsce, MG, Warszawa 2009, s. 15.

${ }^{46}$ P. Boekholt, B. Thuriaux, Public policies to facilitate clusters: background, rationale and policy practices in international perspective, w: Boosting Innovation: The Cluster Approach, OECD, Paris 1999.
} 
Z kolei Trend Chart Report Komisji Europejskiej klasyfikuje modele polityki klastrowej uwzględniające sposoby jej wdrażania z punktu widzenia kierunku i kompleksowości interakcji w systemie innowacyjnym. Raport wyróżnia ${ }^{47}$ :

1) model polityki ukierunkowany na wzmacnianie interakcji w ramach „potrójnej helisy" (triple helix), czyli sytemu powiązań pomiędzy trzema aktorami systemu gospodarczego, tj. sferą nauki, biznesu i administracji; to z kolei, co się dzieje w każdej z helis i w relacjach między nimi, przekłada się na funkcjonowanie systemu społeczno-gospodarczego regionu;

2) model polityki ukierunkowany na powiązania pomiędzy przedsiębiorcami oraz przedsiębiorstwami i instytucjami $\mathrm{B}+\mathrm{R}$;

3) model koncentrujący się na stymulowaniu wszystkich typów interakcji pomiędzy przedsiębiorstwami w ramach klastra i jego otoczenia - w konstelacjach wertykalnych i horyzontalnych.

Wybór właściwego modelu stanowi poważne wyzwanie dotyczące wdrażania polityki klastrowej. Jest on uzależniony od wielu czynników, stąd jego implementacja musi opierać się na szczegółowej analizie sytuacji społeczno-gospodarczo-politycznej. Decyzje odnośnie do wprowadzenia CBP leżą w gestii poszczególnych państw członkowskich. W praktyce gospodarczej najczęściej jest wdrażany model policy-mix, który obejmuje wszystkie obszary jednocześnie.

W określonych państwach członkowskich UE korzysta się z różnych instrumentów i narzędzi przy wprowadzaniu „klasterinigu”. Przede wszystkim jest to uwarunkowane faktem, iż w zależności od kraju członkowskiego, a nawet regionu mamy do czynienia z różnymi typami klastrów, znajdującymi się na różnych etapach rozwoju. CBP nie jest też odrębną polityką prowadzaną przez określone państwo na poziomie narodowym czy regionalnym. Polityka ta jest względem siebie komplementarna, stąd może być ona umiejscowiona jako polityka strukturalna - na poziomie regionów, może też stanowić agendę polityki innowacyjnej, naukowo-technologicznej, bądź mieć charakter horyzontalny, a więc odbywać się na każdym szczeblü .

Dla właściwego umiejscowienia polityki klastrowej ma również znaczenie typ wspierania klastrów. Wspieranie rozwoju klastrów w ramach tradycyjnej polityki przemysłowej wymaga podjęcia tego typu działań w tradycyjnych sektorach. Z kolei polityka wspierania klastrów dla kluczowych w poszczególnych regionach obszarów może być wdrażana w ramach polityki regionalnej, bądź szerszej strukturalnej. Wspieranie powstawania klastrów w sektorach wysokotechnologicznych musi znaleźć oparcie w polityce innowacyjnej. Stymulowanie powstawania małych i średnich

47 European Trend Chart on Innovation, Thematic Report Cluster Policies, European Commission 2003, s. 11-13, za: T. Brodzicki, S. Szultka, P. Tamowicz, op.cit., s. 18.

48 T. Brodzicki, S. Szultka, P. Tamowicz, ibidem, s. 18. 
przedsiębiorstw może wymagać umiejscowienia polityki klastrów w ramach polityki wspierania przedsiębiorczości ${ }^{49}$.

Często podkreśla się, że wdrożenie polityki opartej na klastrach nie wymaga radykalnych przeobrażeń dotychczasowego nurtu prowadzonej polityki. Jej wdrożenie może dokonywać się poprzez modyfikację istniejących instrumentów, ich odpowiednie uwarunkowanie, koordynację działań i przyjęcie jednolitych zasad implementacji.

Rola czynnika publicznego w stymulowaniu rozwoju inicjatyw klastrowych może być znacząca. Działania te mogą polegać na: organizowaniu programów edukacyjnych w zakresie warsztatów i konferencji, wspieraniu prac badawczo-rozwojowych, promowaniu oraz zachęcaniu do uczestniczenia w klastrze, tworzeniu regulacji i form prawnych, inicjowaniu powstawanie klastra, a także na wsparciu w postaci parków technologicznych lub przemysłowych etc. Niemniej wciąż brakuje odpowiedzi na pytanie, w jakim stopniu rząd krajowy powinien koordynować rozwój klastrów, a co powinno zostać w gestii regionów. Tabela 1 przedstawia klasyfikację polityki klastrowej w Unii Europejskiej, wskazując na różnorodne modele jej implementacji.

Tabela 1. Klasyfikacja polityki klastrowej w państwach europejskich

\begin{tabular}{|l|l|l|l|}
\hline \multicolumn{1}{|c|}{ Polityka narodowa } & Polityka regionalna & $\begin{array}{c}\text { Ramy narodowe dla } \\
\text { realizacji polityki regionalnej }\end{array}$ & \multicolumn{1}{c|}{$\begin{array}{c}\text { Brak jednoznacznie } \\
\text { wyodrębnionej polityki }\end{array}$} \\
\hline $\begin{array}{l}\text { Francja, } \\
\text { Luksemburg }\end{array}$ & Belgia, Hiszpania & $\begin{array}{l}\text { Austria, Niemcy, Włochy, } \\
\text { Szwecja, Wielka Brytania }\end{array}$ & $\begin{array}{l}\text { Dania, Grecja, Islandia, Irlandia, Izrael, } \\
\text { Holandia, Norwegia, Portugalia }\end{array}$ \\
\hline $\begin{array}{l}\text { Litwa, Łotwa, } \\
\text { Słowenia }\end{array}$ & Węgry & $\begin{array}{l}\text { Bułgaria, Czechy, Estonia, Polska, } \\
\text { Rumunia, Słowacja }\end{array}$ \\
\hline
\end{tabular}

Źródło: European Trend Chart on Innovation, Thematic Report Cluster Policies, European Commission 2003, s. 11, za: T. Brodzicki, S. Szultka, P. Tamowicz, Polityka wspierania klastrów. Najlepsze praktyki. Rekomendacje dla Polski, Niebieskie Księgi 2004, rekomendacje nr 11, IBnGR, Warszawa 2004, s. 18.

Trend Chart Report jednoznacznie wskazuje, że nie istnieje jeden utarty model wdrażania polityki klastrowej w układzie instytucjonalnym zarówno na poziomie narodowym, jak i regionalnym. W zależności od wybranego modelu w implementację może być zaangażowana jedna instytucja lub ich cały kompleks.

Podsumowując, można domniemywać, że zasadniczym celem polityki opartej na klastrach prowadzonej przez Unię Europejską jest podniesienie konkurencyjności

\footnotetext{
49 Ibidem.
} 
gospodarek narodowych, regionalnych i lokalnych jej państw członkowskich. Polityka wspierania klastrów ze względu na swój horyzontalny charakter stanowi istotny element w tworzącej się nowej ekonomii, gdzie najważniejszym zasobem jest wiedza, zdolności i umiejętności, które umożliwiają współpracę między ludźmi i urzeczywistnianie wspólnych celów. Skłonność do innowacji nie bierze się „znikąd”. Wydaje się, że powstaje ona jako efekt uboczny budowania sieci powiązań, proaktywnych zachowań oraz mieszanki zaufania, norm i wzajemności. Innowacja oparta jest przecież na otwartej postawie, skłonności do podejmowania ryzyka oraz poczuciu oświeceniowego optymizmu wobec rozumu i postępu, który w efekcie ma doprowadzić do lepszych rozwiązań. Klaster zapewnia koncentrację tych cech i stwarza realną szansę na powstanie innowacji poprzez szybki dostęp do uczestników, ich potencjalnych zasobów organizacyjnych, przepływ informacji, wymianę doświadczeń i krzyżowanie się pomysłów na różnych szczeblach. A przecież wytworzenie innowacyjnego, konkurencyjnego produktu jest dźwignią przedsiębiorczości i prowadzi, w określonych okolicznościach, do stabilnego wzrostu gospodarczego ${ }^{50}$.

\section{Cluster based policy as a factor stimulating innovativeness of European Union economy}

Clusters in the European Union policies are significant tool in boosting competitiveness and innovation of enterprises and regions. One of the most important documents in the European Union policy on clusters has been issued in 2008. Therefore, we can observe the emergence of a new kind of policy - cluster based policy. The goal of this article is to show that policy oriented on the clusters is aimed at developing a strategy for rising the competitiveness of regions and enterprises. One can risk the thesis that the concept of clustering is the answer to the question about a new way of generating competitiveness which takes into account a wide range of factors. The issue of clusters is associated with occurrence of a number of benefits for both participants in the cluster and as well as the whole economy. The author identifies and defines them as a benefit at the micro and macro level.

\footnotetext{
50 S. Knack, P. Keefer, Does Social Capital have an Economic Payoff? A Cross-Country Investigation, „The Quarterly Journal of Economics” 11.1997, s. 1283.
} 


\section{Les politiques de clusters comme un facteur stimulant l'esprit d'innovation dans l'économie de l'Union européenne}

Les clusters dans la politique de l'UE constituent un outil important dans le renforcement de la compétitivité et de l'innovation des entreprises et des régions. En 2008 l'un des documents les plus importants de la politique de l'Union européenne sur les clusters et la stratégie d'innovation a été publié. L’objectif principal de cet article est de montrer qu'une politique fondée sur les clusters vise à développer une stratégie pour améliorer la compétitivité des régions et des entreprises. On peut supposer que le concept de clusters est une réponse à la question portant sur une nouvelle façon de créer de la compétitivité, en tenant compte d'un large éventails de facteurs. Le fonctionnement d'un cluster apporte des avantages pour les entités qui en font partie et pour l'ensemble de l'économie. Lauteur les identifie. Ce sont les avantages à la fois au niveau micro et macro. 